\title{
Black Afrikaans: An alternative use
}

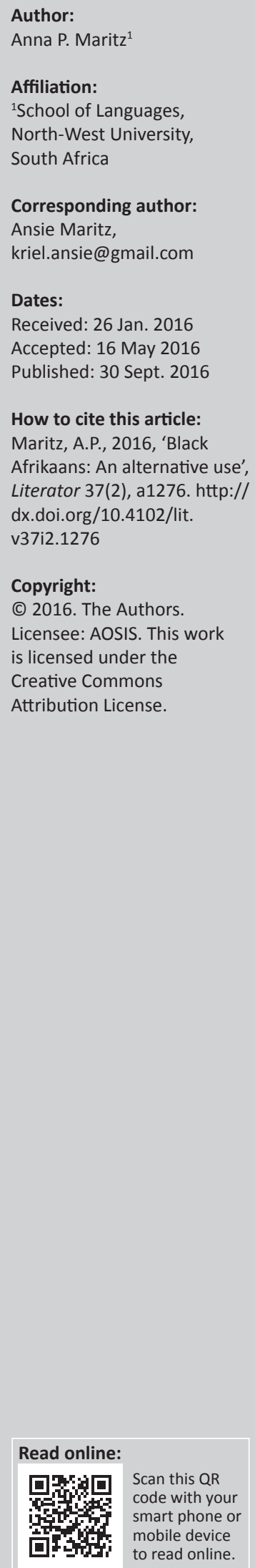

This article provides a first look at the nature of the alternative functions of Black Afrikaans. These functions realise when Black Afrikaans is imitated by Afrikaans mother-tongue speakers. The functions of the alternative use of Black Afrikaans centre on: the social nature of the variety, sensitivity as a deciding role-player, identity, humour, inclusivity and exclusivity, language repertoire and similar variety. Furthermore, because of the direct relationship between Black Afrikaans, Pidginised Afrikaans and the imitation of Black Afrikaans, these varieties are compared to establish a starting point description for the imitation of Black Afrikaans, as the variety has not yet been described.

Swartafrikaans: 'n Alternatiewe gebruik. Die artikel bied 'n eerste oorsig van die aard van die alternatiewe funksies van Swartafrikaans. Hierdie funksies realiseer wanneer Swartafrikaans deur Afrikaansmoedertaalsprekers nagemaak of nagepraat word. Die funksies van die alternatiewe gebruik van Swartafrikaans sentreer rondom: die sosiale aard van die variasie, sensitiwiteit as 'n bepalende rolspeler, identiteit, humor, inklusiwiteit en eksklusiwiteit, taalrepertoire en ooreenkomstige variasies. Weens die direkte verhouding tussen Swartafrikaans, Gepidginiseerde Afrikaans en die napraat van Swartafrikaans, word dié variëteite ook vergelyk om sodoende ' $n$ aanvangsbeskrywing vir die napraat van Swartafrikaans daar te stel aangesien dié variëteit nog nie beskryf is nie.

\section{Introduction}

Black Afrikaans is a non-standard variety of Afrikaans and is considered as the Afrikaans an African language mother-tongue speaker speaks. When Black Afrikaans is used among Afrikaans mother-tongue speakers and not in its usual way, between an African language mother-tongue speaker and an Afrikaans mother-tongue speaker, it becomes the imitation of Black Afrikaans. As Black Afrikaans is not used for its original function, the function is changed to an alternative function. The nature of this undescribed variety's functions has not received attention as of yet. To gain knowledge about its nature I used the theory of varieties closely associated - Black Afrikaans and Pidginised Afrikaans - to describe the characteristics and properties of the imitation of Black Afrikaans.

As the imitation of Black Afrikaans shares properties with these closely associated varieties, the latter's functions are applicable and were used as a starting point to identify respondents on the Potchefstroom campus of the North-West University. If and when the respondents suggested different or other functions, they were recorded. The data were collected by using questionnaires, e-mail interviews and a focus group interview.

\section{Imitating Black Afrikaans: The nature of the variety Stylising Black Afrikaans}

The imitation of Black Afrikaans shares properties of Black Afrikaans and Pidginised Afrikaans. Black Afrikaans is a non-standard, non-mother-tongue variety of Afrikaans and can be seen as an interlanguage (De Wet 1993:171, 1996:7; Du Plessis 1987:24-25). The concept 'imitation' of Black Afrikaans can be compared to the following similar language phenomena: Mock Ebonics, language crossing and the process of stylising language.

Mock Ebonics is 'a system of graphemicphonetic grammatical, semantic and pragmatic strategies for representing an out-group's belief in the imperfection and inferiority of Ebonics and its users'

Note: This article is adapted from the author's MA degree 'Die alternatiewe funksies van Swartafrikaans' at the Department of Afrikaans and Dutch, North-West University, Potchefstroom Campus, South Africa, with supervisor Prof. Jako Olivier, received May 2015, available here: https://dspace.nwu.ac.za/bitstream/handle/10394/15343/Kriel_AP.pdf?sequence=1\&isAllowed=y 
(Ronkin \& Karn 1999:360). Language crossing is another language phenomenon to take note of in this regard. Language crossing 'involves code alternation by people who are not accepted members of the group associated with the second language that they are using' (Rampton 1995:485). Speakers imitate language varieties other than a variety considered to be their own. Lopez (2009) refers to two types of crossing: Crossing in which the speaker imitates for comedic purposes and crossing in which the speaker genuinely attempts to represent the language or dialect as accurately as possible. When an Afrikaans mother-tongue speaker uses Black Afrikaans, it is possible for the speaker to implement the variety in both of these ways.

Another theoretical consideration is stylisation. According to Coupland (2001:345) stylisation is the 'knowing deployment of culturally familiar styles and identities that are marked as deviating from those predictably associated with the current speaking context.' When an Afrikaans mother-tongue speaker imitates Black Afrikaans they use a variety other than the expected one. In such a context the imitation of Black Afrikaans becomes a marked form. The process in which a language variety is used to perform 'non-current-first-person personas' using phonological and related elements is called dialect stylisation (Coupland 2001:345). Such a performance could involve play or parody where performance refers to a speaker's conscious and somewhat autonomous design of their speech, being aware of the alternative possibilities and possible outcomes (Coupland 2001:345, 2007:146).

Bell and Gibson (2011:557) distinguish between everydayand staged performance. In the current study the imitation of Black Afrikaans can be compared to everyday performance as the speakers use it in a specific mode in everyday conversations (see Bell \& Gibson 2011:557). It can also be associated with a performer- and an audience role, just like a staged performance (Bell \& Gibson 2011:557). In the case of an Afrikaans mother-tongue speaker imitating Black Afrikaans, the Afrikaans mother-tongue speaker would be the performer and probably another Afrikaans mothertongue speaker or speakers, the audience. It is also possible that the audience may vary, depending on who the Afrikaans mother-tongue speaker is aiming their performance at or who overhears the stylised conversation.

When speakers stylise each other's languages, it is important to keep in mind that this kind of stylisation could carry a risk of misinterpretation (Higgins 2015:135-136). Higgins (2015:141) further reminds us that reported speech could potentially be experienced as being an offensive form of mockery, especially when the speaker stylises their language in such a way that it becomes crossing.

Speakers can, on the other hand, stylise their own speech through managing their multilingual resources to perform certain identities (Coupland 2007:146; Higgins 2015:141).
Afrikaans mother-tongue speakers could imitate Black Afrikaans to construct and portray certain identities they associate with the variety. According to Bell and Gibson (2011:561-562) identity includes:

structurated and agentive dimensions. It is in part product, the result of the social milieu, chances and structures which an individual has experienced. And it is in part process, something negotiated and constructed rather than just being there. Identity involves both similarity and difference, identification with and divergence from an other or others.

It is important to take into account that the dynamic nature of linguistic identities, and the complicated nature of voice ownership through stylisation, could influence the function Afrikaans mother-tongue speakers' imitate Black Afrikaans for as well as how it is received and interpreted (see Coupland 2007:183; Higgins 2015:135-136). Some dialects are strongly associated with a certain culture (Bell \& Gibson 2011:555; Coupland 2007:2). Coupland (2007:2) refers to dialects as evolving social styles that carry contemporary and historical associations. These social- and dialect styles can serve as a resource for speakers to create different kinds of personal as well as interpersonal meanings (Coupland 2007:3).

As discussed in the following section, there are certain cultural and contextual factors that are associated with Pidginised Afrikaans and Black Afrikaans. Because of the close relation between these varieties and the imitation of Black Afrikaans, the same cultural and contextual factors must be taken into consideration when the functions of the imitation of Black Afrikaans are determined.

\section{Closely associated varieties: Pidginised Afrikaans and Black Afrikaans}

The imitation of Black Afrikaans can display both negative and positive functions. The possibility that some of the imitation of Black Afrikaans' functions can still be used for or experienced as being negative points to the sensitivity surrounding this variety. The sensitivity surrounding Black Afrikaans, and therefore the imitation of Black Afrikaans, resides in the political-historical background of South Africa (see Chick 1995:238-239; Du Plessis \& Du Plessis 1987:14; Steyn 2014:313-318; 389-393).

Black Afrikaans can also be defined as Afrikaans as an African language mother-tongue speaker would speak it (Stoltz 1982:21; Van Wyk 1983:163). On the other hand, Pidginised Afrikaans is Black Afrikaans as an Afrikaans mother-tongue speaker would imitate it, in combination with the adjustment or simplification of his or her mothertongue (see Van Wyk 1983:163). Considering the properties of Pidginised Afrikaans, it might seem the same as the imitation of Black Afrikaans. The difference between these varieties (including Black Afrikaans) can be ascribed to a shift in emphasis and will be explained according to three main factors. 
TABLE 1: Table to compare the three closely associated varieties: Pidginised Afrikaans, Black Afrikaans and the imitation of Black Afrikaans: In so doing a broad, first description of the imitation of Black Afrikaans can be composed.

\begin{tabular}{|c|c|c|c|c|}
\hline Variety & Speakers & $\begin{array}{l}\text { Relation between the speakers and the } \\
\text { context of use }\end{array}$ & Function & Compilation of the variety $\dagger$ \\
\hline Pidginised Afrikaans & $\begin{array}{l}\text { Afrikaans mother-tongue } \\
\text { speaker (AMS) } \\
\text { towards } \\
\text { African language } \\
\text { mother-tongue speaker } \\
\text { (AFMS) }\end{array}$ & $\begin{array}{l}\text { - Often in a work relationship } \\
\text { - Often power relationship between } \\
\text { speakers } \\
\text { - Speech accommodation }\end{array}$ & $\begin{array}{l}\text { Used for basic communication } \\
\text { (regularly in a work context) }\end{array}$ & $\begin{array}{l}\text { - Language universalia: Universal grammar } \\
\text { Imitation of Black Afrikaans, combined with } \\
\text { elements of Standard Afrikaans as part of } \\
\text { the speaker's mother tongue. } \\
\text { - Communication strategy: Adjustment of } \\
\text { Afrikaans as mother tongue (regularly to } \\
\text { accommodate) } \\
\text { - Mother-tongue interference: Uses mother } \\
\text { tongue as a support }\end{array}$ \\
\hline Black Afrikaans & $\begin{array}{l}\text { African language } \\
\text { mother-tongue speaker } \\
\text { (AFMS) } \\
\text { to } \\
\text { Afrikaans mother-tongue } \\
\text { speaker (AMS) }\end{array}$ & $\begin{array}{l}\text { - Often in a work relationship } \\
\text { - Often power relationship between } \\
\text { speakers } \\
\text { - Speech accommodation } \\
\text { - Learner's variety }\end{array}$ & $\begin{array}{l}\text { Used for basic communication } \\
\text { (regularly in a work context): }\end{array}$ & $\begin{array}{l}\text { - Language universalia: Universal grammar } \\
\text { - Language exposure: Imitation of Standard } \\
\text { Afrikaans or Afrikaans that speaker is } \\
\text { exposed to in combination with elements of } \\
\text { speaker's African mother-tongue. } \\
\text { - Communication strategy: Adjustment of } \\
\text { African language. Language learner speaks } \\
\text { Afrikaans and adjusts to AMS's language. } \\
\text { - Mother-tongue interference: Uses mother } \\
\text { tongue as a support }\end{array}$ \\
\hline $\begin{array}{l}\text { Phenomenon: } \\
\text { Imitation of Black } \\
\text { Afrikaans }\end{array}$ & $\begin{array}{l}\text { Afrikaans mother-tongue } \\
\text { speaker (AMS) } \\
\text { to } \\
\text { Afrikaans mother-tongue } \\
\text { speaker (AMS) }\end{array}$ & $\begin{array}{l}\text { - Socially more equal relationship } \\
\text { - Power relationship between AMSs } \\
\text { and AFMSs could influence function } \\
\text { - Informal context } \\
\text { - Safe environment or social circles }\end{array}$ & $\begin{array}{l}\text { Function is not crucial or necessary- } \\
\text { mainly has a supplementary } \\
\text { function, for example: } \\
\text { - Accuracy and story telling } \\
\text { - Supplementary to the } \\
\text { individual's language repertoire } \\
\text { - To construct inclusivity and } \\
\text { exclusivity } \\
\text { - To create a specified identity } \\
\text { - Humour } \\
\text { - To make language use more } \\
\text { interesting }\end{array}$ & $\begin{array}{l}\text { - Language universalia: Universal grammar } \\
\text { - Language exposure: Imitation of Black } \\
\text { Afrikaans according to exposure to the variety } \\
\text { itself, possibly also according to the speaker's } \\
\text { exposure to factors of BSAE (further study is } \\
\text { needed) in combination with elements of } \\
\text { Standard Afrikaans as mother tongue. } \\
\text { - Communication strategy: Adjustment of } \\
\text { Afrikaans as mother-tongue language to } \\
\text { imitate the communication strategy of } \\
\text { AFMS's that use Black Afrikaans. } \\
\text { - Mother-tongue language interference: Use } \\
\text { mother tongue as medium of support. }\end{array}$ \\
\hline
\end{tabular}

†, De Wet, 2009:15458; \$, De Wet, 2009:156.

Source: Adapted from Kriel, A.P., 2015, 'Die alternatiewe funksies van Swartafrikaans', MA Dissertation, Department of Afrikaans and Dutch, North-West University, Potchefstroom Campus, South Africa

The first difference between Pidginised Afrikaans and the imitation of Black Afrikaans is seated in the speakers who use these varieties. Pidginised Afrikaans is used by an Afrikaans mother-tongue speaker towards an African language mothertongue speaker. On the other hand, when Black Afrikaans is imitated it is used by one Afrikaans mother-tongue speaker to another Afrikaans mother-tongue speaker. ${ }^{1}$ In Pidginised Afrikaans the emphasis is on an Afrikaans mother-tongue speaker who accommodates ${ }^{2}$ the non-native speaker by simplifying his or her language versus the imitation of Black Afrikaans, where Afrikaans mother-tongue speakers try to speak Black Afrikaans as accurately as possible in which instance Black Afrikaans fulfils the role of a target language ${ }^{3}$ to the Afrikaans mother-tongue speaker.

The third main difference is contingent on the function which these varieties fulfil. Pidginised Afrikaans serves as an interlanguage and communication medium between an Afrikaans mother-tongue speaker and an African language mother-tongue speaker. When Black Afrikaans is imitated by Afrikaans mother-tongue speakers its function changes to functions alternative to the reason why Black Afrikaans originated. These alternative functions are investigated in the article.

The three varieties can be presented as follows (see Table 1), which serves as a broad, first description of the imitation

\footnotetext{
1.The term includes Afrikaans mother-tongue speakers of any culture. It also does not rule out the possibility of the imitation of Black Afrikaans being used by speakers of mother-tongue languages other than Afrikaans.
}

2.See accommodation theory (Crystal 2008:369; Van Wyk 1983:162).

3.See target language and second language acquisition (Adendorff 2014:444). of Black Afrikaans. This description is compiled by using the two closely related varieties to the imitation of Black Afrikaans: Pidginised Afrikaans and Black Afrikaans. Further study is needed to identify the structural differences.

As the imitation of Black Afrikaans has not yet fully been described, the familiar terms, pidgin and jargon are used to identify possible functions of the variety. When Black Afrikaans is imitated, the imitation is of a pidgin language and can therefore share similar functions to that of a pidgin (see De Wet 1993:174, 1996:2). In sociolinguistics a pidgin refers to a language that frequently evolves out of necessity and from a colonial situation, has a reduced grammatical structure, lexicon and stylistic scope and has no mothertongue speakers (Akmajian et al. 2010:294, 594; Crystal 2008:369; Gilmore 2011:371; Holm 2000:5; Joseph 1996:14; Matras 2009:60).

According to De Wet (1993:172), a pidgin is known through its properties which results from its originating process and its restricted function as a contact language. As mentioned, the studied variety entails Black Afrikaans as a pidgin language being imitated and used among speakers of the same language as compared to speakers of different languages and therefore cannot be a pidgin language in its original sense.

The unique character of the imitation of Black Afrikaans can also be compared to the social function of a jargon. A jargon is a set of lexical items that is used by certain professions or by a specialised social group (Akmajian et al. 2010:588). Although the social elements of a jargon are applicable to the imitation 
of Black Afrikaans, its language structure is not. Jargon consists mainly of detached language concepts and does not necessarily emerge out of an already existing language structure (Nash 1993:3).

With relation to Hudson (2000:418), it is possible that Afrikaans mother-tongue speakers use Black Afrikaans as a jargon for specific social functions, for example showing group inclusivity and exclusivity. According to Mühlhäusler (1986:5) the term jargon can also be exchanged with the terms pre-pidgin, multilingual idiolect or secondary hybrid. A possible term that could be used as a name for the imitation of Black Afrikaans and similar varieties is a 'multilingual idiolect', seeing as this term embraces the possibility of individuals ultimately using the imitation of Black Afrikaans as an extension of their language repertoire or language elements they 'claim' for themselves as part of an idiolect.

\section{Identifying possible functions}

By using the functional properties of a jargon and a pidgin, it is possible to compile functions that the imitation of Black Afrikaans can fulfill. It is therefore also important and valuable to take the findings of similar studies into account.

In Rupp's study, The function of Student pidgin in Ghana, she identifies the reasons why Ghanaian students who are proficient in Standard English choose to speak Pidgin. These functions entail the following: In-group language, to portray a selected group identity, reinforcing solidarity within a certain social group and to distinguish between different groups, therefore construing exclusivity (Rupp 2013:14, 20). In the article A Moroccan accent in Dutch, A sociocultural style restricted to the Moroccan community? Nortier and Dorleijn (2008:125-142) discuss the phenomenon where an ethnic accent with Moroccan characteristics evolved in Dutch. According to Nortier and Dorleijn $(2008: 128,131)$ the Moroccan accent is used to create identity, fun and humour ${ }^{4}$. The same as the imitation of Black Afrikaans, the speakers of this accent integrate the language wilfully into their own language (see Nortier \& Dorleijn 2008:128).

In Jaspers' thesis (2004:1) he refers to Moroccan youth sometimes using language to mock and undermine. He calls this undermining process 'belachelijk... doen' or to ridicule oneself and classifies it as being a type of acting. (Jaspers 2004:1). According to Mühlhäusler (1986:84) a jargon can also be supplementary to an individual's language use in the same way. It can serve as an extension of an individual's language repertoire (Mühlhäusler 1986:84).

By using already determined functions of pidgin and jargon and understanding the functions stylising one's language

4. Humour is a, complex piece of equipment for living a mode of attack and a line of defence, a method of raising questions and criticizing arguments, a protest against the inequality of the struggle to live, a way of atonement and reconciliation, a treaty with all that is wilful, impaired, beyond our power to control' (Nash 2013:1). can provide, it is possible to anticipate similar functions when Black Afrikaans is used alternatively. The classification of Black Afrikaans as a non-standard variety can also be used to classify the imitation of Black Afrikaans.

\section{Classifying the imitation of Black Afrikaans as a variety}

If the imitation of Black Afrikaans is seen as a unique variety it should also be possible to classify it. Because the imitation of Black Afrikaans originates from Black Afrikaans the studied variety could initially also be classified as a nonstandard variety or a dialect variety (De Wet 1993:186, 1996:7). However, a further classification is needed. The imitation of Black Afrikaans could be a sub-variety of Black Afrikaans as Afrikaans mother-tongue speakers imitate Black Afrikaans and it is therefore not being used in its original state. This variety, namely the imitation of Black Afrikaans, is further defined by inter-language properties by which the speaker, who imitates the variety, uses elements of his or her own variety or mother-tongue language. To refer to these interlanguage properties the imitation of Black Afrikaans can further be classified as an 'inter-variety'. Although the presented term needs further refinement, the imitation of Black Afrikaans and similar varieties can be classified as a sub-dialectic inter-variety. The order of classification is set out in Figure 1.

To identify the nature of the alternative functions of Black Afrikaans, a qualitative study was undertaken as set out below.

\section{Method}

\section{Research design and research aim}

The study is a qualitative study as this research methodology is of help within a study where restricted, little or no information is available about a specific phenomenon (Croker 2009:9). The aim of the study is to identify how the alternative functions

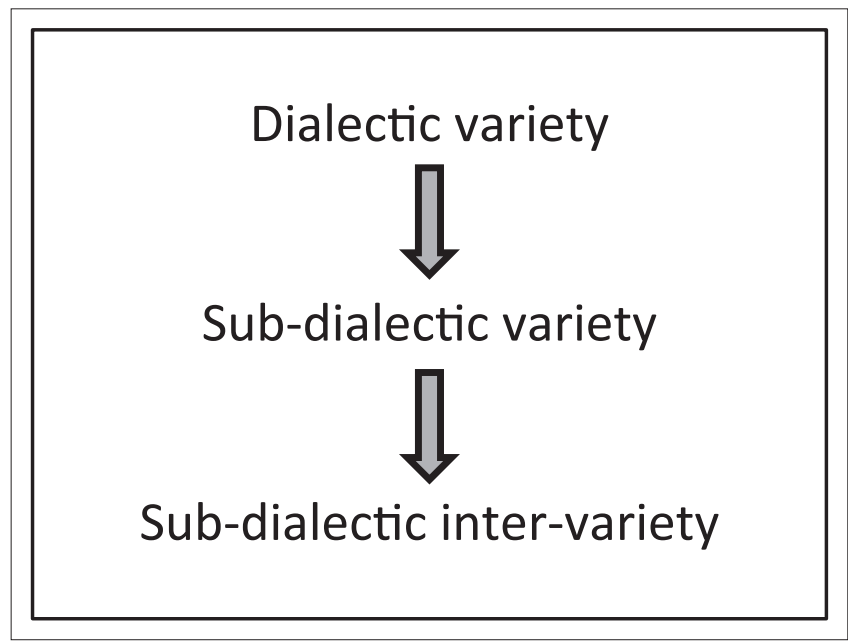

Source: Adapted from Kriel, A.P., 2015, 'Die alternatiewe funksies van Swartafrikaans', MA Dissertation, Department of Afrikaans and Dutch, North-West University, Potchefstroom Campus, South Africa

FIGURE 1: Exposition to explain the classification order of the imitation of Black Afrikaans as a language variety. 
of Black Afrikaans are realised among Afrikaans mother-tongue speakers. The supporting data were gathered accordingly.

\section{Research group and sample taking}

After ethical clearance was received (ethic code: NWU-0006614-S7), a pilot study was carried out with 35 second-year students taking Afrikaans-Dutch as a subject at the NorthWest University, Potchefstroom campus. Minimal changes were made to the questionnaires with the result that the respondents that participated in the pilot study could be added to the total of respondents (see Van Teijlingen \& Hundley 2001). Questionnaires were given to a group of 191 students of the North-West University, Potchefstroom campus. The participating students in this group are mainly white Afrikaans mother-tongue students. These students were first year students from different study fields, taking a compulsory academic literacy module at the university.

After the questionnaires were examined, a focus group interview was held with five brown Afrikaans mother-tongue students of the same campus, one of whom turned out to be an English mother-tongue speaker, but also made a reasonable contribution. Simultaneously an e-mail interview was held with two Black Afrikaans mother-tongue speakers who were previously students at North-West University, Potchefstroom campus. The respondents added up to 233 in total. The respondents participated voluntarily in the study and were kept informed throughout the research process.

\section{Research instrument}

The data were collected by using a semi-structured questionnaire, a focus group interview and two e-mail interviews. The data were inductively deduced from the researched phenomenon which forms part of the Grounded theory (Strauss \& Corbin 1990:23).

\section{Research procedure and data processing}

Because a similar study has not yet been done, informal conversations were held at first to confirm that the variety does exist before the study was undertaken. A pilot study was carried out with 35 respondents after which a few adjustments were made. These questionnaires were included in the total number of questionnaires as the changes to its structure were minor and the feedback was valuable.

As the data were not saturated after just using questionnaires, a focus group interview and e-mail interviews were held with the respondents as indicated above. The focus group interview was transcribed and the questionnaires were computerised after which the data were coded by using the program Atlas.ti (2014). Coding is the process through which the transcribed data is divided into meaningful, analytical unities (Nieuwenhuis 2007:105; Saldaña 2009:3). Codes are created throughout the processing of the data. Some codes also have sub-codes (Saldaña 2009:11).
During the analysis the reliability of the results was tested by using inter-judge reliability. After the test was performed, the Kappa-coefficient was calculated ${ }^{5}$. The Kappa-coefficient was calculated by using SPSS Inc. (2014) with a result of 0.707 $(p<0.001)$.

\section{Data-analysis and discussion}

In this section the nature of the alternative functions of Black Afrikaans is determined by analysing the data with the use of Atlas.ti. The previously identified functions, from a theoretical perspective as well as from similar studies (see discussion above), were used as a starting point to create potential codes. As the coding process proceeded, the researcher added codes according to the data. The researcher used an inductive method as a starting point to identify certain codes.

After the coding process was completed, the codes were sorted into thematic groups, which were again sorted into three descriptive sections. These sections are: (1) Functional role players, (2) Functions of the variety and (3) Nature of the variety. The seven main themes are sorted according to these three sections, each described by referring to their different codes. There are 14 codes in total. Some of these themes are not functions in themselves, but contains important information to understand the alternative functions of Black Afrikaans. Figure 2 is represented as a visual summary at the beginning of the description.

Each of the texts used in Atlas.ti are numbered:

- Assimilated text from questionnaires: number 1

- E-mail interview: number 2

- E-mail interview: number 3

- Focus group interview: numbers 4 and 5

- Only one focus group interview was held although there are two transcribed texts

The discussion will take the following form: The main theme at hand is indicated after which this theme is elaborated by referring to the relevant codes. After the code is mentioned, certain representative quotes of the code are selected and discussed. An English translation will follow after the original quote(s). If the question asked in the questionnaires or during the interviews is needed to contextualise the respondent's answer, the question (printed in italics) is included at the beginning of the relevant codes. The network in Figure 2 shows the nature of the functions of the imitation of Black Afrikaans according to different sections, themes and codes.

\section{Functional role players}

The functional role players refer to social and sensitivity factors that play an important role in the possible functions Afrikaans mother-tongue speakers imitate Black Afrikaans for. These role players also portray elements of the context and conditions within which Black Afrikaans is imitated.

5.This was done with the help of the North-West University's Statistical Consultation Service. 


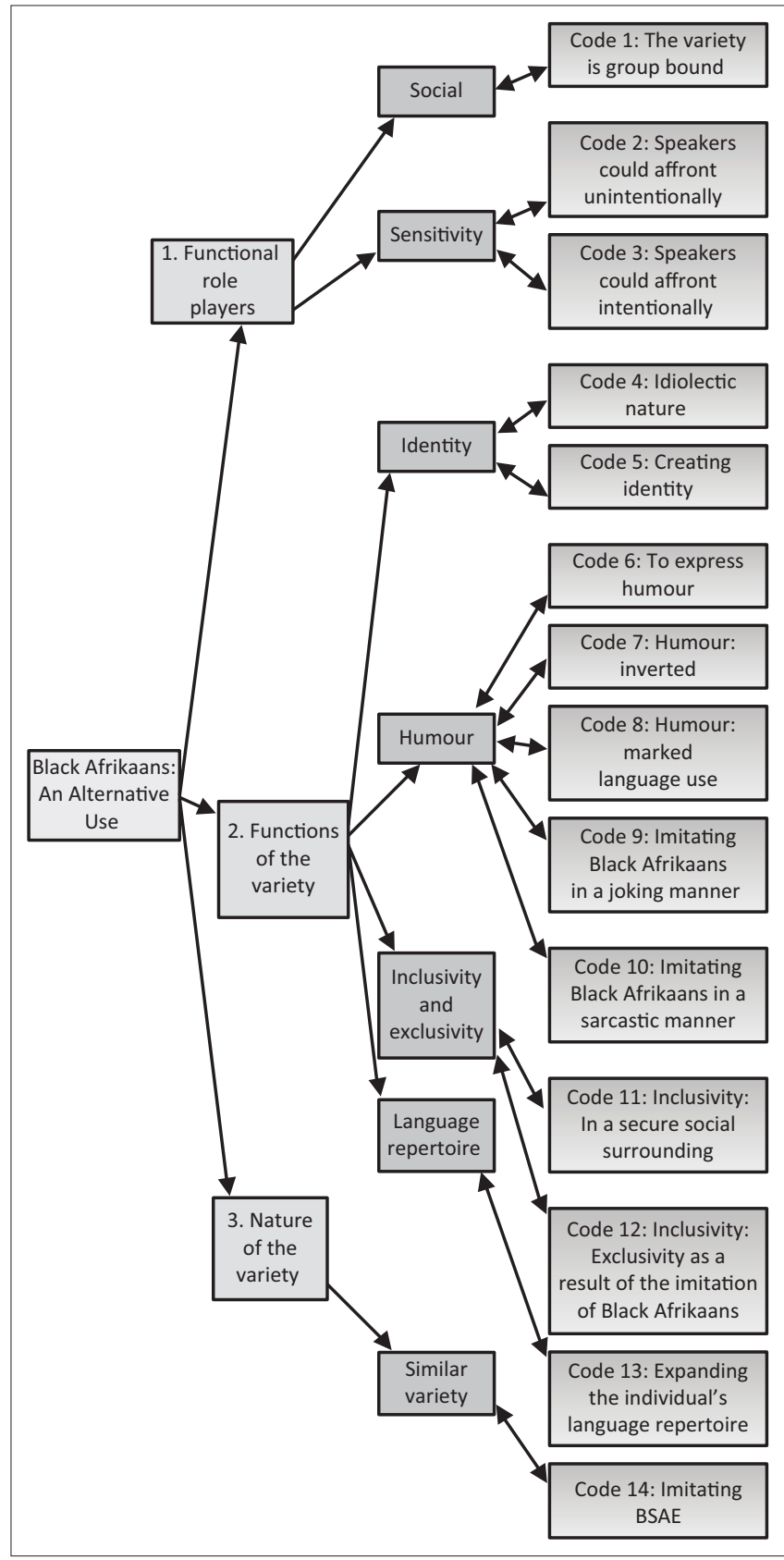

Source: Adapted from Kriel, A.P., 2015, 'Die alternatiewe funksies van Swartafrikaans', MA Dissertation, Department of Afrikaans and Dutch, North-West University, Potchefstroom Campus, South Africa

FIGURE 2: A network of the relevant codes to indicate the nature of the alternative functions of Black Afrikaans. The network can be used to understand the layout of the discussion. The different codes are divided into different themes.

Social: The social facet of language comes into play when Black Afrikaans is imitated. It would seem that language users prefer imitating Black Afrikaans in a safe social surrounding, for example within the safe borders that a social group can provide.

\section{Code 1: The variety is group bound (1-1)}

Speakers prefer to imitate Black Afrikaans in a social group where they feel safe. It is possible that the function may differ between social groups (see Coupland 2007:3):

As dit net ons kleurlinge is. Ons verstaan mekaar, ons weet waaroor gaan dit, dan sal ons dit gebruik, ja [4:16]. [If it is only us coloureds.
We understand each other, we know what it is about, then we will use it.]

Quote [4:16] serves as an answer to the question as to when the respondents will imitate Black Afrikaans. Considering this answer, the respondents prefer a specific social group as a place of mutual understanding and therefore as a safe structure within which a variety such as Black Afrikaans can be imitated. This mutual understanding directly signals group exclusivity and the social function of a jargon (see codes 11, 12 and 14). It would seem that when these speakers use the imitation of Black Afrikaans as a resource, they are well aware of the sensitivities surrounding this form of social stylisation (see Coupland 2001:345, 2007:3; Higgins 2015:141).

Sensitivity: The sensitivity surrounding the imitation of Black Afrikaans is a direct product of the strong association between Black Afrikaans as a language variety and African language mother-tongue speakers. As indicated, this association should be read against the socio-political history of South-Africa. Sensitivity also entails withholding the use of Black Afrikaans in the presence of a Black Afrikaans speaker or an African language mother-tongue speaker in fear of affronting such a speaker.

\section{Code 2: Speakers could affront unintentionally (25-1)}

The Afrikaans mother-tongue speaker makes use of the imitation of Black Afrikaans but does not want to affront a Black Afrikaans speaker or an African language mothertongue speaker. Because of the risk of misinterpretation, it could happen that a speaker affronts another speaker without aiming to do so (see Higgins 2015:135-136):

Dit is nie 'n neerhalende gebruik om só Afrikaans te praat nie, slegs ' $n$ resultaat van kulture wat kontak maak; Hulle sal kan identifiseer met die konteks beskou en dit dus humoristies vind. [1:54] [It is not a disparaging use to speak Afrikaans in this manner, it is only a result of cultures that want to make contact. They can identify with the context and therefore find it humoristic.]

Mense moet verder begin dink wanneer hulle iets doen of gebruik wanneer oningeligtheid, ingeligtheid word, moet mense anders begin optree. [2:26] [People must begin to think further when they do something or use something - when uninformed becomes informed, people must start behaving differently.]

In [1:54] and [2:26] there are two different approaches to using Black Afrikaans. According to the first respondent [1:54] it is not wrong to imitate Black Afrikaans. Considering the context within which a speaker uses Black Afrikaans, the respondent feels that it need not be a sensitive case rather than a humoristic one.

On the other hand the respondent in [2:26] feels that people think too simply about the imitation of Black Afrikaans and should, when they are informed about the sensitivities surrounding the variety, use it more responsibly. Higgins (2015:141, 136) and Coupland (2007:146) also point out the possibility of a speaker stylising speech in a more positive or negative way. 
Quotes [1:69] and [1:99] serve as commentary on the following question and answer:

Question: If you and a friend use Afrikaans amongst yourselves as an African language speaker would speak it, how do you think the African language speaker would feel when you and your friend speak in this way?

Selected answer: I do not use it when someone is close by that uses Black Afrikaans themselves or if they know someone who speaks Black Afrikaans:

Omdat ek respek wil toon aan daardie persoon en dit sou verwag van sy/haar kant ook. [1:69] [Because I want to show respect to that person and expect it from his or her side too.]

Ek probeer nie om 'n Swartafrikaans sprekende se taal te spot nie, dus praat ek nie voor hulle nie, anders sal hulle dink ek mok hulle taal en ek doen nie. [1:99] [I try not to mock a Black Afrikaans speaker's language, therefore I do not speak in front of them, otherwise they will think I am mocking their language and that is not what I am doing.]

Participant (P): 'Daaaar'. So ja, ek sal nou nie iemand spot sommer so nie. Ek sal - Nee, rêrig, ek is te bang. ['Theeere'. So yes, I wouldn't mock someone just like that. I will - No, really, I am too scared.]

Researcher (R): Maar, so jy sal nogal 'n wit Afrikaans spot nè? [But, so you will quite mock a white Afrikaans?]

P: Ja, ek sal. [Yes I will.]

Group (G): [lag] [laughing]

P: Ek sal - Want julle sal, julle vat dit soos rêrig as 'n grap. Hulle sal dit nie as 'n grap vat nie, hulle sal rêrig- [I will - Because you will, you will take it as a joke. They will not take it as a joke, they will really-]

P: Hulle sal ons attack! [They will attack us!]

G: [lag] Ja! [laughing] Yes!

[4:24]

The respondents in [1:69], [1:99] and [4:24] take a more similar stand to that of quote [2:26] and emphasise the possibility of the imitation of Black Afrikaans that has the potential to affront speakers and could even create potential friction between cultural or ethnic groups [4:24]. It is clear that the respondents know the risk of stylising their language through imitating Black Afrikaans which could potentially lead to speakers' deliberate misuse of Black Afrikaans.

\section{Code 3: Speakers could affront intentionally (7-2)}

A speaker can deliberately misuse the imitation of Black Afrikaans to affront African language mother-tongue speakers by stylising their language as crossing (see Higgins 2015:141).

Relevant question to quote [1:5]: Do you think that there are people who would misuse Black Afrikaans so they can affront the hearer?

P: Definitief. Wat dit kliphard doen. Al is hulle in watter situasie. Die vakansie toe het ons van die kuierplek af gery en my vriende agterin die kar was dronk... ek en my vriend sit nou hiervoor. Toe trek polisiemense ons af. Joh, en toe's dit toevallig swart mense en hulle begin praat sommer so dronk in Swartafrikaans, aspris. En ek is laaik dis nou nie 'n situasie waar jy daai moet gebruik nie. Ek weet jy's nou kwaad want... omdat jy afgetrek word, maar dis nie jy wat afgetrek word op die agterste sitplek nie; dis die persoon hier voor wat die moeilikheid kry. Jis, ek het só groot geskrik. Hulle was sommer net, '[in Swartafrikaans aksent] nee, ma dis mos nou die swart mense...' [1:5] [Definitely. That will do it aloud. Even if they are in whatever situation. This holiday we drove back from the club and my friends at the back of the car were drunk... me and my friend are sitting in front, Then police people pulled us over. Joh, and then it was accidentally black people and they spoke in their drunkenness Black Afrikaans, deliberately. And I was like this is not a situation where you should use that. I know you are angry because... because you are being pulled over, but it isn't you sitting at the back seat that are being pulled over; it's the person here at the front that is going to get the trouble. Jis, I had súch a fright. They were just, '[in Black Afrikaans accent] no, but it is the black people...']

Jy spot met mense wat gebroke Afrikaans praat (dit beteken nie hulle is dom nie, dit beteken hul is nie jou taal magtig soos jy nie) [2:12] [You are joking with people that speak a broken Afrikaans (it does not mean that they are stupid, it means that they have not mastered the language as you have.)]

Not one of the respondents indicated that they imitate Black Afrikaans to affront an African language mother-tongue speaker although, according to the respondent's reaction in [1:5], it does happen.

In quote [2:12] the respondent directly associates the imitation of Black Afrikaans with mocking the African language mother-tongue speaker's intelligence. Even though the speaker does not intend to affront the listener or hearer with his or her imitation of Black Afrikaans, the listener or hearer might interpret the speaker's intention as being negative.

Whether positive or negative, Afrikaans mother-tongue speakers can use the imitation of Black Afrikaans to fulfil the following functions.

\section{Functions of the variety}

The imitation of Black Afrikaans can be used for the following functions as discussed below:

Identity: Speakers can create identity by associating themselves with others or distancing themselves from others on certain points (see Bell and Gibson 2011:561-562). It is also possible that a speaker can manage their multilingual resources in such a way to perform certain identities (see Coupland 2007:146; Higgins 2015:141).

\section{Code 4: Idiolectic nature (20-1)}

Speakers can imitate Black Afrikaans to express themselves better. By associating with the variety and implementing elements of the imitation of Black Afrikaans, they can create a linguistic self-identity through their language use:

Om myself beter uit te druk [1:64] [To express myself better.]

Vir party word dit ' $n$ ideolek [2:15] [It becomes an idiolect for some.]

P: I think also when it comes to the Afrikaans people, they have different slang, and then you just pick up on everyone. Like, say this person. 
Has a type of slang that they use when they speak Afrikaans, then you like, 'oh, okay', and then you have another person. And then you have like a third person. And they use their slang, and you like, 'oh, okay'. Then you sort of mix those slang together. So ja.

R: Soos jou eie taal amper wat jy maak. [Like your own language that you create.]

P: Ja. [Yes]

[4:40, 4:41]

When an Afrikaans mother-tongue speaker makes use of certain Black Afrikaans language elements in her or his way of conversing, these language elements can form part of the individual's idiolect. An individual might imitate Black Afrikaans to make his or her language more interesting or even to try and communicate as clearly as possible [1:64]. When quote [4:40, 4:41] is considered, the language could be used to add to speaker authenticity. The alternative term Mühlhäusler (1986:5) mentions for a pidgin, namely 'multilingual idiolect', directly correlates with code 4 .

The imitation of Black Afrikaans is also used to create identity. This function is in accordance with the studies mentioned about a Ghanaian Student pidgin and a Moroccan accent in Dutch (Nortier \& Dorleijn, 2008:128, 131; Rupp 2013:14, 20).

\section{Code 5: Creating identity (18-1)}

Gives accuracy to a situation and includes the possibility of acting out a specific identity other than the speaker's own:

Ek sal slegs hierdie vorm van Afrikaans gebruik om 'n situasie beter te verduidelik of in ' $n$ graperige bedoeling [1:5] [I will only use this form of Afrikaans to explain a situation better or in a humorous meaning.]

Maak iemand na, maak grappe ens. [1:106] [Imitate someone, make jokes etc.]

Slegs as ek iets aan iemand verduidelik (Namaak - vermaaklik) [1:6] [Only if I explain something to someone. (Imitate entertaining)]

In quotes [1:5], [1:106] and [1:6] the respondents imitate Black Afrikaans in an attempt to explain a situation, action or character more accurately. A speaker can portray an individual's characteristics by making use of their language variety, in this case Black Afrikaans (see dialect stylisation, Coupland 2001:345). In so doing the speaker is acting out the verbal characteristics of another individual. Jaspers (2004:1) calls this process 'belachelijk... doen' or to ridicule oneself. This kind of language performance can also be associated with a staged performance where the speaker would be the performer, acting out a specific persona to the listener as the audience. It is also possible for an individual to create humour in this way.

Humour: Afrikaans mother-tongue speakers can imitate Black Afrikaans to add humour to their speech. Humour can have different functions, some with positive and others with negative connotations (see Nash 2013:1 in footnote 4).

\section{Code 6: To express humour (42-4)}

By imitating Black Afrikaans, speakers can express humour:

Dit is vir humor, veral onder vriende [2:14] [It is for humour, especially among friends.]

Wanneer ek snaaks wil wees... [1:16] [When I want to be funny...]

Sommer as ek laf wil wees en 'n grappie wil maak. Ek hou daarvan om snaaks te wees [1:32] [When I merely want to be silly and make a good joke. I like it to be funny.]

Afrikaans mother-tongue speakers can imitate Black Afrikaans to integrate humour into a conversation. This function is similar to the reason why Dutch mother-tongue speakers sometimes use a Moroccan accent (Nortier \& Dorleijn 2008:131).

'Humour' as indicated in code 6 is further defined from codes $7-10$.

\section{Code 7: Humour: inverted (2-1)}

Instead of imitating Black Afrikaans in order to share humour with another Afrikaans mother-tongue speaker, the speaker anticipates that an African language mothertongue speaker would find it humoristic when they hear an Afrikaans mother-tongue speaker imitate Black Afrikaans.

[1:123] serves as commentary on the following question and answer:

Question: If you and a friend use Afrikaans amongst yourselves as an African language speaker would speak it, how do you think the African language speaker would feel when you and your friend speak in this way?

Selected answer: Other feeling, specify:

Hulle sal dink dit klink snaaks omdat ek dit nie oor die algemeen doen nie. [1:123] [They will think it sounds funny because I don't generally do it.]

In quote [1:123] humour is presented in an inverted way. Instead of the Afrikaans mother-tongue speaker finding it humorous to imitate Black Afrikaans, the Afrikaans mothertongue speaking respondent assumes that an African language mother-tongue speaker would find it humorous if the respondent uses Black Afrikaans which is out of the ordinary. Here Coupland's (2001:345) definition of stylisation explains this kind of marked form as deviating from styles and identities 'predictably associated with the current speaking context'.

\section{Code 8: Humour: Marked language use (4-1)}

Black Afrikaans in itself can be experienced as a marked form in specific contexts. In this way the language variety might be amusing to Afrikaans mother-tongue speakers, possibly creating the desire to perform or imitate Black Afrikaans themselves:

P: Ek dink omdat ons nie gewoonlik so praat nie en nou is dit iets anders. Dan's dit nou meer in terme van grap maak en so. 
[I think because we don't usually speak like that and now it is something different. Then it is more in terms of a joke and so.]

P: Ja, soos ons kom straight van ' $n$ kleurling-gebied af. Daar's nie regtig swart mense daar nie, so as ' $n$ mens dit hoor da is dit ' $n$ bietjie snaaks, of vreemd. [Yes, so we come straight from a coloured region. There aren't really black people there, so when you hear it, it is a bit funny, or odd.]

$[4: 21]$

As mentioned in code 7 , it is possible that humour is caused by the uniqueness in the case of an Afrikaans home-language speaker using Black Afrikaans compared to Standard Afrikaans or Cape Afrikaans under 'normal' circumstances. In the case where friends use it [4:21], it might be even more humorous as the friends know each other's usual way of conversing well.

\section{Code 9: Imitating Black Afrikaans in a joking manner (33-1)}

The imitation of Black Afrikaans can be used to make jokes, for example among friends:

Soms by die huis as ons met mekaar spot; As ons grappe maak [1:29] [Sometimes at home when we mock each other; When we make jokes.]

Wanneer ek en my vriende mekaar afkraak [1:18] [When me and my friends belittle each other.]

Within code 9 there are strong individual differences. Respondents interpret the imitation of Black Afrikaans in different ways and from different perspectives on the imitation of Black Afrikaans. A stigma surrounding the imitation of Black Afrikaans as portrayed in quotes [1:29] and [1:18] can share as an end product with similar qualities to those of Mock Ebonics and crossing (see Lopez 2009; Ronkin \& Karn 1999:373-374). In the respondents' case, the imitation of Black Afrikaans is stylised in this way among friends [1:18] or even a family [1:29].

The reason why code 9 and code 10 still forms part of humour as a theme is because of the vast functional possibilities humour presents (see Nash 2013:1). It would also seem as if the respondents reflect on the imitation of Black Afrikaans in a humoristic way whether it portrays positive or negative connotations.

\section{Code 10: Imitating Black Afrikaans in a sarcastic manner (5-1)}

An Afrikaans mother-tongue speaker could imitate Black Afrikaans in a sarcastic way in order to affront an African language mother-tongue speaker. The imitation of Black Afrikaans can also be interpreted in a sarcastic way:

Wil nie die persoon seermaak nie, maar weet party mense hou daarvan om so 'n persoon 'uit te haal' oor hoe hulle praat. [1:81] [Don't want to hurt the person, but know that certain people like it to 'pick on' a person about how they speak.]

Dit kan beslis. As ek'n Afrikaansprekende na maak wat swak Engels praat, bv. Is you hungry? I are very hungry. I where watching to...ens. Ek lewer so kommentaar op dié mense se vermoëns om ' $n$ ander taal te praat. Ek spot hulle. Net omdat iemand nie ' $n$ taal kan praat nie beteken dit nie hulle is dom nie. [2:19] [It can for certain. If I imitate an
Afrikaans speaker who speaks bad English, e.g. Is you hungry? I are very hungry. I where watching tv... etc. In this way I am criticising those people's ability to speak another language. I am mocking them. Just because someone cannot speak a language, it doesn't mean that they are stupid.]

The imitation of Black Afrikaans can be used to mock an African language mother-tongue speaker by being sarcastic [1:81] but can, as mentioned above, also be switched around by a speaker to specifically mock the Afrikaans mothertongue speaker [2:19]. Code 10 also projects tangency with Mock Ebonics and crossing (see Lopez 2009; Ronkin \& Karn 1999:373-374). The multi-faceted nature of the imitation of Black Afrikaans comes forth when the different functional layers of one function is taken into consideration.

The dynamic nature of the imitation of Black Afrikaans could also be influenced by the complicated nature of voice ownership, when the variety is stylised (see Coupland 2007:183; Higgins 2015:135-136). For example the respondent in quote [1:81] is a white Afrikaans mothertongue speaker and the respondent in [2:19] is a Black Afrikaans mother-tongue speaker. That these two respondents' take on the same subject is similar in a way, yet different if their possible feeling of voice ownership is taken into consideration.

By using the imitation of Black Afrikaans a speaker can create inclusivity and exclusivity in a group situation.

Inclusivity and exclusivity: An Afrikaans mother-tongue speaker can use the imitation of Black Afrikaans in order to emphasise whether an individual is an insider of a group or an outsider.

\section{Code 11: Inclusivity: In a secure social surrounding (3-2)}

Afrikaans mother-tongue speakers prefer to use the language variety in a context where they feel safe and understood:

' $n$ Noue vriendekring. Soos ons verstaan mekaar hoe dit gaan. Dis nie almal wat dit altyd verstaan nie [4:19] [A close circle of friends. Like we understand each other how it goes. It isn't everyone that always understand it.]

Wanneer ek om sekere vriende is en grapperig voel [1:40] [When I am around certain friends and feel humorous.]

It seems that if a speaker feels safe to imitate Black Afrikaans, it would be in a social setup where there is a good understanding of the function of the variation itself (see quotes [4:19] and [1:40]). The secure, social and accepting surroundings that a specific social group can offer seems to be safe enough for an Afrikaans mother-tongue speaker to imitate Black Afrikaans. The imitation of Black Afrikaans could be used to create interpersonal meanings exclusive to a certain group (see Coupland 2007:3).

Code 12: Inclusivity: Exclusivity as a result of the imitation of Black Afrikaans (42-2)

When the imitation of Black Afrikaans is used as a form of inclusivity by a group, it has exclusivity of the group as direct 
result. Imitation of Black Afrikaans can be stylised by a group in such a way that it has the same function as jargon.

Because Black Afrikaans is imitated in a secure social group or context, the direct effect of an inclusive function will be exclusivity. The social group, within which Black Afrikaans is imitated, will be exclusive as there is a definite difference between members of the group and others that are not part of the group. According to Hudson (2000:418) a jargon can, among other functions, be used to create group inclusivity and exclusivity.

The imitation of Black Afrikaans can serve as one of the primary factors that bind a group, consisting of two or more members, together. On a secondary level the language variety that forms a binding factor within a group can be used as a sociolect and creates an exclusive effect when someone uses it. See quotes [1:89], [1:23] and [4:15]:

As ek by ' $n$ sekere groep praat [1:89] [When I speak in a certain group.]

Ekgebruik dit soms wanneer ek met my gesin praat [1:23] [I sometimes use it when I speak to my family.]

P: Ons het nie regtig soos aan die buitekant gebruik nie, ons sal dit soos as ons in ' $n$ vertrek is, alleen is. As dit net ons kleurlinge is. Ons verstaan mekaar, ons weet waaroor gaan dit, dan sal ons dit gebruik, $j a$. [We didn't really like use it on the outside, we will like when we are in a room alone. If it is only us coloureds. We understand each other, we know what it is about, then we will use it, yes.][4:15]

In [1:23] the respondent's exclusive group consists of his or her family whereas in [4:15] the main exclusivity factor is seated in the ethnicity of the group. It would seem that the inclusive and therefore exclusive function that the imitation of Black Afrikaans can fulfil is subordinate to the main or primary group combining factor.

To explain the functional value of jargon even further, the following examples are given:

Omdat dit ' $n$ 'ding' is wat ons het, dus is dit soos ons geheime taal [1:68] [Because it is a 'thing' we have, therefore it is like our secret language.]

Om vriende; dit is ons tiener taal [1:103] [Around friends; it is our teenager language.]

Hulle het baie kodes vir sekere woorde wat die swart mense byvoorbeeld gebruik. So hulle gebruik- Soos my ma sal 'n woord gebruik en dan's daar ' $n$ anderkleur- swart mens daar, maar hy weet nie wat sy sê nie, maar-Verstaan, die $X^{6}$-gesin byvoorbeeld, verstaan wat daar aangaan [4:39] [They have many codes for certain words that the black people for example use. So they use - Like my mother will use a word and then there is a differently coloured - black person there, but he doesn't know what she is saying, but- See, the X-family, for example, understands what is going on there.]

As discussed, the terms pidgin and jargon are used in this study to identify the nature as well as possible functions of 6.The X-insertion indicates the deletion of the family's surname to keep them anonymous. the imitation of Black Afrikaans. In this case the functions of a jargon that Mühlhäusler (1986:5) identifies are present in the respondent's responses (see [1:68] and [1:103]). These functions entail: inclusivity and exclusivity (see codes 1112 ), idiolect (see code 4 ) and the forming of identity (see code 5).

When a group or an individual becomes acquainted with the imitation of Black Afrikaans, the variety becomes supplementary to their language repertoire, expanding their choice of multi-lingual resources (see Coupland 2007:146).

Language repertoire: The imitation of Black Afrikaans provides an Afrikaans mother-tongue speaker with extra multi-lingual resources, expanding the individual's language repertoire.

\section{Code 13: Expanding the individual's language repertoire} (25-1):

By becoming familiar with the imitation of Black Afrikaans, an Afrikaans mother-tongue speaker can acquire a larger pool of linguistic resources:

Want dit is ' $n$ manier van praat [1:76] [Because it is a way of speaking.]

Dit word na 'n tydperk 'n gewoonte om hierdie woorde te gebruik [1:86] [It becomes a habit after a while to use these words.]

Ek het dit aangeleer by ander mense [1:109] [I learnt it from other people.]

According to the respondent in [1:76], the imitation of Black Afrikaans could be part of an individual's daily conversational speech (see Bell \& Gibson 2011:557). When the respondents' statements in [1:86] and [1:109] are considered, the imitation of Black Afrikaans provides language elements that expand the individual's language repertoire. The individual speaker now has a greater selection of language items to choose from when he or she is in a conversation. As mentioned, Mühlhäusler (1986:84) indicates that a jargon can be supplementary to an individual's language use and form an extension of an individual's language repertoire.

\section{Nature of the variety}

The functions mentioned in the 'functional role players' section could also be relevant for similar varieties such as Black South African English (BSAE).

Similar variety: It is possible to identify similar South African related language varieties to the imitation of Black Afrikaans. In doing so, the identified functions can be tested by repeating a similar study on these varieties.

\section{Code 14: Imitating Black South African English (2-1)}

BSAE could be considered as a similar variety to Black Afrikaans with the possibility of speakers imitating the variety: 
Ek en my ma byvoorbeeld in die dorp loop, dan, julle ken daai mense wat die pamflette so uitdeel? So, 'oh, gorgas! Gorgas (gorgeous)', dan is hulle so en dan sê ons net vir mekaar, 'hier kom gorgas'! [4:7] [Me and my mother for example walk in town, then, you know those people that distribute flyers? So, 'oh gorgas! Gorgas (gorgeous)', then they are like that and then we say to each other 'here comes Gorgas'!]

R: En dink julle, soos, sê nou maar die media het ook 'n invloed? Dit wat mense hoor op TV, sê nou maar president Zuma praat nou? Wel, dis nou in Engels, maar daar's ook ' $n$ Engelse manier van so praat. [And do you think, for instance the media also has an influence? What people hear over the TV, just say president Zuma speaks? Well, this is in English, but there is also an English way of speaking in this way.]

P: Ja. [Yes.]

P: Beslis. [For certain.]

P: Engelse swart-Swartengels, ja. [English black-Black English, yes.] [4:39]

The universality of the phenomenon, namely the alternative use of a certain variety, is apparent. As portrayed by the responses in [4:7] and [4:39], varieties such as BSAE could also be imitated in the same way as Black Afrikaans is imitated. Further study is needed in this regard.

\section{Synthesis}

After identifying the codes it can be sorted into different themes. The imitation of Black Afrikaans is a social phenomenon and is used in social groups where the speaker feels safe enough to do so. A speaker can use it to add to his or her own 'unique' language as an individual, expanding his or her language repertoire. By imitating Black Afrikaans, it is also possible for a speaker to stylise their language in such a way as to portray identities other than his or her own. Because of the sensitivity surrounding this variety, speakers are wary of imitating Black Afrikaans in the presence of an African language mother-tongue speaker. The imitation of Black Afrikaans can also be used to affront the last mentioned, whether it is on purpose or by accident.

When a speaker integrates the imitation of Black Afrikaans, he or she can also create humour in their language. The variety can also serve as an instrument to show, create and strengthen inclusivity and exclusivity of and in a social group. The imitation of Black Afrikaans also shows similar properties of a jargon and a sociolect. It would seem that a similar variety to the imitation of Black Afrikaans could be the imitation of BSAE, although further study is needed in this regard.

\section{Conclusion}

The main functions of the alternative use of Black Afrikaans are: The creating of identity through language, integrating positive or negative humour, to bring about inclusivity and exclusivity - sometimes by using the imitation of Black Afrikaans as jargon - and expanding the individual's language repertoire. The imitation of Black Afrikaans has a social nature and because of Black Afrikaans' politicalhistorical background, there is sensitivity surrounding the imitation of Black Afrikaans. The sensitivity also serves as a deciding factor in a speaker's choice whether to imitate Black Afrikaans or not. Further, concerning the nature of the imitation of Black Afrikaans, it is important to notice that a function can consist of more than one facet.

The classification of the imitation of Black Afrikaans as a language variety could have a universal value for language varieties that are similar for example the imitation of BSAE. The identified functions might be the same when language speakers imitate similar language varieties to Black Afrikaans.

The description and the classification of the imitation of Black Afrikaans and the identification of the alternative functions of Black Afrikaans, create a stepping stone for further research and in the end an expanded, thorough description of the imitation of Black Afrikaans as a language variety.

\section{Acknowledgements Competing interests}

The author declares that she has no financial or personal relationships which may have inappropriately influenced her in writing this article.

\section{References}

Adendorff, E., 2014, 'Taalverwerwing en taalonderrig', in W.A.M. Carstens \& N. Bosman (reds.), Kontemporêre Afrikaanse Taalkunde, pp. 443-469, Van Schaik, Pretoria.

Akmajian, A., Demers, R.A., Farmer, A.K. \& Harnish, R.M., 2010, Linguistics: An introduction to language and communication, 6th edn., MIT Press, Cambridge, MA.

ATLAS.ti, version 7.5.2., 2014, viewed n.d., from http://atlasti.com/

Bell, A. \& Gibson, A., 2011, 'Staging language: An introduction to the sociolinguistics of performance', Journal of Sociolinguistics 15(5), 555-572. http://dx.doi. org/10.1111/j.1467-9841.2011.00517.x

Chick, J.K., 1995, 'Interactional sociolinguistics and intercultural communication in South Africa', in R. Mesthrie (ed.), Language and social history: Studies in South African sociolinguistics, pp. 230-241, David Philip, Claremont, CA.

Coupland, N., 2001, 'Dialect stylization in radio talk', Language in Society 30, 345-375.

Coupland, N., 2007, Style: Language variation and identity, University Press, Cambridge. http://dx.doi.org/10.1017/CBO9780511755064

Croker, R.A., 2009, 'An introduction to qualitative research', in J. Heigham \& R.A. Croker (eds.), Qualitative research in applied linguistics, pp. 3-24, Palgrave Macmillan, New York. http://dx.doi.org/10.1057/9780230239517_1

Crystal, D., 2008, A dictionary of linguistics and phonetics, 6th edn., Blackwell, Malden, MA. http://dx.doi.org/10.1002/9781444302776

De Wet, A.S., 1993, 'Swart Afrikaans as niestandaard variëteit van Afrikaans', SuidAfrikaanse tydskrif vir taalkunde 11(suppl 18), 170-188. http://dx.doi.org/10.108 0/10118063.1993.9724495

De Wet, A.S., 1996, 'Swart Afrikaans as 'n aanleerdersvariëteit in die Vrystaat: 'n studie aan die hand van intertaalteorie', Fakulteit Lettere en Wysbegeerte, Universiteit van die Vrystaat.

De Wet, A.S., 2009, 'Swartafrikaans', in D. Hugo (red.), Halala Afrikaans, pp. 153-161, Protea Boekhuis, Pretoria.

Du Plessis, H., 1987, Variasietaalkunde, Serva-Uitgewers, Pretoria.

Du Plessis, H. \& Du Plessis, T., 1987, 'Inleiding', in H. Du Plessis \& T. Du Plessis (reds.), Afrikaans en taalpolitiek: 15 opstelle, pp. ix-xv, HAUM, Pretoria.

Gilmore, P., 2011, 'We call it "Our Language”: A children's Swahili pidgin transforms social and symbolic order on a remote hillside in up-country Kenya', Anthropology \& Education Quarterly 42(4), 370-392. http://dx.doi.org/10.1111/ j.1548-1492.2011.01145.x

Higgins, C., 2015, 'Insults or acts of identity? The role of stylization in multilingual discourse', Multilingua 34(2), 135-158. http://dx.doi.org/10.1515/multi-2014-1006 
Holm, J.A., 2000, An introduction to pidgins and creoles, Cambridge University Press, Cambridge. http://dx.doi.org/10.1017/CBO9781139164153

Hudson, G., 2000, Essential introductory linguistics, Blackwell, Oxford.

Jaspers, J., 2004, 'Tegenwerken, belachelijk doen: talige sabotage van Marokkaanse jongens op een Antwerpse middelbare school. Een sociolinguïstische etnografie' PHD-proefskrif, Universiteit van Antwerpen.

Joseph, H., 1996, Language history, language change and language relationship, Mouton de Gruyter, Berlin.

Kriel, A.P., 2015, 'Die alternatiewe funksies van Swartafrikaans', MA Dissertation, Department of Afrikaans and Dutch, North-West University, Potchefstroom Campus, South Africa.

Lopez, Q., 2009, 'Imitation or influence: White actors and Black language in film', in Seventeenth Annual Symposium about Language and Society, Austin, TX, April 10-11, pp. 110-120.

Matras, Y., 2009, Lanquage contact, Cambridge University Press, Cambridge. http:// dx.doi.org/10.1017/СBO9780511809873

Mühlhäusler, P., 1986, Pidgin and Creole linguistics, Blackwell, Oxford.

Nash, W., 1993, Jargon: Its uses and abuses, Blackwell, Oxford.

Nash, W., 2013, The language of humour, Routledge, New York.

Nieuwenhuis, J., 2007, 'Analysing qualitative data', in K. Maree (ed.), First steps in research, pp. 99-122, Van Schaik, Pretoria.
Nortier, J. \& Dorleijn, M., 2008, 'A Moroccan accent in Dutch: A sociocultural style restricted to the Moroccan community?', International Journal of Bilingualism 12(1/2), 125-142. http://dx.doi.org/10.1177/13670069080120010801

Rampton, B., 1995, 'Language crossing and the problematisation of ethnicity and socialisation', Pragmatics 5(4), 1-20. http://dx.doi.org/10.1075/prag.5.4.04ram

Ronkin, M. \& Karn, H.E., 1999, 'Mock Ebonics: Linguistic racism in parodies of Ebonics on the internet', Journal of Sociolinguistics 3(3), 360-380. http://dx.doi. org/10.1111/1467-9481.00083

Rupp, L., 2013, 'The function of student pidgin in Ghana', English Today 29, 13-22. http://dx.doi.org/10.1017/S0266078413000412

Saldaña, J., 2009, The coding manual for qualitative researchers, Sage, London.

Steyn, J.C., 2014, Ons gaan 'n taal maak: Afrikaans sedert die Patriot-jare, Kraal, Pretoria.

Stoltz, E., 1982, 'Gepidginiseerde Afrikaans in wit-swart-interaksie', MA-verhandeling Fakulteit Lettere en Wysbegeerte, Randse Afrikaanse Universiteit.

Strauss, A. \& Corbin, J., 1990, Basics of qualitative research, Sage, Belmont.

Van Teijlingen, E.R. \& Hundley, V., 2001, 'The importance of pilot studies', Socia Research Update, 35, viewed 8 December 2016, from http://sru.soc.surrey.ac.uk/ SRU35.pdf

Van Wyk, E.B., 1983., 'Gepidginiseerde Afrikaans', in G.N. Claassen \& M.C.J. Van Rensburg (reds.), Taalverskeidenheid: 'n Blik op die spektrum van taalvariasie in Afrikaans, pp. 162-170, Nasionale Boekdrukkery, Kaapstad. 